\title{
The Improvement Effort in Evaluation Study Using Problem Based Learning on Hydrology Subject
}

\author{
Nurhayati Aritonang, Ninik Wahju Hidajati \\ Civil Engineering Department, Engineering Faculty \\ Universitas Negeri Surabaya \\ Surabaya, Indonesia
}

\begin{abstract}
The subject of hydrology at the faculty of civil engineering department water resources is a basic subject that must be fully understood and acknowledged by both students of the faculty of authenticable civil engineering department and faculty of educational civil engineering department. Fundamental condition needed the result of the observation data within all aspects of precipitation, surface run-off, stream flow, infiltration, percolation and evaporation. Therefore, the process of learning requires a good learning pattern. Usually the education model uses lecture-oriented class, which can result in difficulty to understand the basic hydrology subject due to analyzing Water Resources (like calculating water discharge, counting the rain precipitation, etc.) Therefore, research is suggesting Problem Based Learning (PBL) model which ensures the growth sense of motivation, active-learning, independency, responsibility and comprehension in learning Hydrology subject by using multimedia facility (Video lecturing, students presentation, and exemplary picture). Serving a wide variety of video on Hydrology and practical props as a component of the tools used in everyday life with models and methods are expected to be able to encourage the emergence of self-reliance and stimulate student motivation in getting optimal understanding. This is supported by Learning Availability Tools, Semester Learning Plan (RPS), Contextual Lesson Plan (SAP), Student Worksheet and Evaluation Sheet systematically.
\end{abstract}

Keywords-Hydrology, Motivation, Evaluation, Unit Lecture Event (SAP)

\section{INTRODUCTION}

Hydrology subject at the Faculty of Engineering Department of Civil inundated the basic subjects that must be understood and mastered by students of a purely civilian and students PTB. Basically the science of hydrology is not an entirely exact science, but it is a science that requires interpretation. Jobs - jobs in hydrology experiments are very limited by the size of natural events and by research into things - certain things. Terms - a fundamental requirement that the need is data - the data observed in all aspects of precipitation, runoff (run off), stream-flow, infiltration, percolation, evaporation, and others. With these data and supported by experiences in much science related to hydrology, and then a hydrologist will be able to provide a solution in relation to the technical planning of the building - the building of water.
While teaching in the observations and experiences during this time, the learning process is generally centered on the lecturer (teacher-oriented). Students only heard faithfully and passive in the learning process that is in line with lectures alone. As a result, an understanding of the science of hydrology as an introduction to the basic science and civil engineering fields inundated more specific the basis for understanding. This case study was undertaken by the means of two directions using the video and power point.

Students' opinions are as follows: the delivery of content is boring and less able to understand and be understood, since the learning hour is at 13:00 implemented on a sleepy hour, they are exhausting because at the beginning of the course is starts with theory. Moreover, the lecturer is less friendly towards students' work. He/she only judged the group presentation display without any further explanation to be understood. The tone of his/her speaking to deliver the lesson is flat that it is difficult to understand. In short, these are some factors of the learning failure that causes lack of human resources lecturer of the course. Mastery of the material, availability and preparation of learning tools such as models of learning, teaching and learning interactions, field experience in taking the example application are needed. Lecturers should obtain a solution as a motivator for learning and seek to improve understanding of the students as the main goal in this hydrological study.

The implementation of PBL model will provide high motivation and more opportunities for students to learn independently or in groups in understanding the material. One way to the above problems is that it is necessary to study a class action in the Hydrology subject. This research will endeavor to increase the motivation to learn in studying and absorbing Hydrology subject, so the obtained understanding is used as the provision of courses and learning to be more readily, especially in irrigation engineering courses.

From the results, some problems that can be identified in Hydrology subject in the Department of Civil Engineering, Universitas Negeri Surabaya are as follows:

- Low yield Hydrology subject affects the understanding.

- The current emphasis on the teacher-oriented needs a touch and fresh initiative to make the learning be more interesting and meaningful. 
- Hydrology subject students found difficulties in understanding the presented material.

- The response of students to learn is still low.

- There is still low in monitoring and evaluation of lecturers during the learning process.

The purpose of this paper is to improve the learning outcomes on hydrology subject in civil engineering students at Universitas Negeri Surabaya.

The purposes of this research are:

- to determine whether the application of the model of Problem Based Learning (PBL) can improve learning outcomes in Hydrology subject for civil engineering students at Technical Faculty of Universitas Negeri Surabaya.

- to know the advantages and disadvantages of the application of Problem Based Learning (PBL).

\section{LITERATURE REVIEW}

\section{A. Assessment Theory}

\section{1) Learning and Teaching}

Learning is the most basic activity in human learning process especially in achieving the institutional objectives of an educational institution or school. This suggests that the success or failure of an education goal depends on how the learning process experienced by individuals. According to [3], learning is a process of change in behavior due to their training and experience. Usman [5] argues that learning can be interpreted as a change in behavior of the individual, the interaction between individuals, and individuals with their surroundings so that they are able to interact well with their environment.

Based on some expressed opinions, the editorial of course is different from one another. However, all of the opinions refer to the goals, objectives, and the same concept and have the same elements as well, namely:

- the existence of individual learning.

- the existence of learning as a process.

- learning outcomes as a result of changes in behavior.

- the learning process occurs in the interaction with the environment.

\section{2) Hydrology}

The Civil Building Engineers are really interested in building the planning and exploitation of water resources, namely water for review control of the use of water, especially that regulate of the river flow, dam - reservoirs and irrigation channels. Therefore, they need to know the science of hydrology use widespread.
3) Problem Based Learning (PBL)

PBL engages students in the inquiry choices which enable them to interpret and explain real-world phenomena and to build understanding of the phenomena. Learning is not designed to help teachers convey large amounts of information to students who are more likely to direct learning and lectures. PBL is designed to help students:

- develop thinking skills, problem solving, and intellectual.

- studying the roles of adults with live up to these roles through situations of real or simulated.

- being independent, autonomous and students.

Here are described and discussed the three purposes above. PBL ultimately strives to provide and help students become independent and students are able to govern themselves (selfregulated students). Teachers/lecturers continuously guide the students by encouraging them to ask questions and provide rewards for weighty questions they ask. With the encouragement of the students to find solutions to real problems are formulated by themselves, then they learn to handle the tasks of finding these solutions independently.

TABLE I. TEACHER BEHAVIOR INDICATOR ON PROBLEM BASED LEARNING

\begin{tabular}{|c|l|l|}
\hline Phase & \multicolumn{1}{|c|}{ Indicator } & \multicolumn{1}{|c|}{ Teacher Behavior } \\
\hline 1 & $\begin{array}{l}\text { Students } \\
\text { orientation at } \\
\text { issue }\end{array}$ & $\begin{array}{l}\text { Explaining the purpose of learning, } \\
\text { explaining the necessary logistics, and } \\
\text { motivating students engage in problem } \\
\text { solving activities }\end{array}$ \\
\hline 2 & $\begin{array}{l}\text { Organize students } \\
\text { to learn }\end{array}$ & $\begin{array}{l}\text { Helping students learn to define and } \\
\text { organizing tasks related to the issue }\end{array}$ \\
\hline 3 & $\begin{array}{l}\text { Guiding } \\
\text { experience of } \\
\text { individual/group }\end{array}$ & $\begin{array}{l}\text { Encouraging students to gather the } \\
\text { appropriate information and carrying out } \\
\text { experiments to get an explanation and } \\
\text { problem solving }\end{array}$ \\
\hline 4 & $\begin{array}{l}\text { Develop and } \\
\text { present work }\end{array}$ & $\begin{array}{l}\text { Assisting students in planning and } \\
\text { preparing the appropriate work such as } \\
\text { reports and help them to share tasks with } \\
\text { friends }\end{array}$ \\
\hline 5 & $\begin{array}{l}\text { Analyze and } \\
\text { evaluate the } \\
\text { problem solving } \\
\text { process }\end{array}$ & $\begin{array}{l}\text { Helping students to reflection or } \\
\text { evaluation of their investigations and the } \\
\text { process they use }\end{array}$ \\
\hline
\end{tabular}

PBL characteristics are as follows:

- problems are starting points in learning.

- the raised issues are problems that exist in the real world of unstructured.

- problems require multiple perspectives (multiple perspectives).

- problems, challenging the knowledge possessed by students, attitudes and competencies that then require the identification of learning needs and a new area of study. 
- learning self-direction becomes the main thing.

- utilization of diverse sources of knowledge, use, and evaluation of resources is an essential process in the PBL.

- learning is collaborative, communication, and cooperative.

- development of inquiry and problem solving skills are as important as mastering content knowledge to find solutions to a problem.

- transparency in PBL processes include the synthesis and integration of a learning process.

- PBL involves the evaluation and review the student experience and learning.

\section{4) Motivation}

Motivation comes from the word "motive". It is defined as "the driving force that has become an active". Another opinion also says that motivation is "the state in the one who encouraged him to undertake activities to achieve the goal".

According to Mc. Donald [3], motivation is the energy change in a person characterized by the emergence of feelings and reactions to achieve the goal. In this sense, it can be said that motivation is complex. Motivation will lead to a change in the energy present in humans, so it will cling to the issue of psychiatric symptoms, feelings and emotions, to then act or do something. Thomas L. Good and Jere B. Braphy define motivation as a driving force and steering, which can strengthen and encourage someone to behave. It means the act of a person depends on the underlying motivations.

While the overall motivation to learn is the driving force both from within and from outside the student (by creating a series of businesses to provide certain conditions) which ensures continuity and provide direction on learning activities, so that the desired destination by a subject of study that can be achieved. Motivation to learn can also be interpreted as a series of businesses to provide certain conditions, so someone willing and wanting to do something, and if he does not like, it will seek to eliminate or circumvent the feeling did not like it.

\section{5) Multimedia}

Multimedia is a means of media in which there are a mix (combination) of various forms of information elements, such as text, graphics, animation, video, interactive and sound as a support to achieve its goal of conveying information or just provide entertainment for its target audiences. Multimedia is often used in entertainment such as games. Multimedia word itself is derived from the multi (Latin) which means a lot and media (Latin) means something that is used to convey something. Multimedia can be categorized into two kinds, namely linear multimedia and interactive multimedia. Linear Multimedia is a multimedia that is not equipped with any control device that can be operated by the user. Multimedia is running sequential (sequential / straight), for example: TV and movies. While a multimedia interactive multimedia is equipped with a controller (or aids, computer, mouse, keyboard, etc.) that can be operated by the user, so the user can choose what they want to proceed. Interactive multimedia combines and synergizes all media consisting of text, graphics, audio, and interactivity (draft).

\section{B. Frameworks}

One model of learning which typically plays the role of teachers/lecturers thrusting authentic problems, facilitates the investigation of students, and fully supports learning in achieving the goal of learning is the Problem Based Learning (PBL). The implementation of PBL model can provide more opportunities for students to learn independently and collectively pose a problem and question, do authentic research, and collaborate to find a solution in addressing the problems that exist with the best creative and full initiative.

\section{Hypothesis Action}

Based on the above framework of thinking, the research hypothesis of this class action is the adoption of a model with the use of multimedia integrated PBL and practical props can increase the motivation and the understanding of the Hydrology subject at the Department of Civil Engineering students Technical Faculty at Universitas Negeri Surabaya.

\section{METHOD}

\section{A. Study Design}

According to Kemmis and Taggart, action research can be seen as a spiral cycle of preparation of planning, action, observation, and further reflections may be followed by the next spiral cycle. Practice class act that was easily developed by Kemmis and Taggart can be described with a flowchart (Fig. 1).

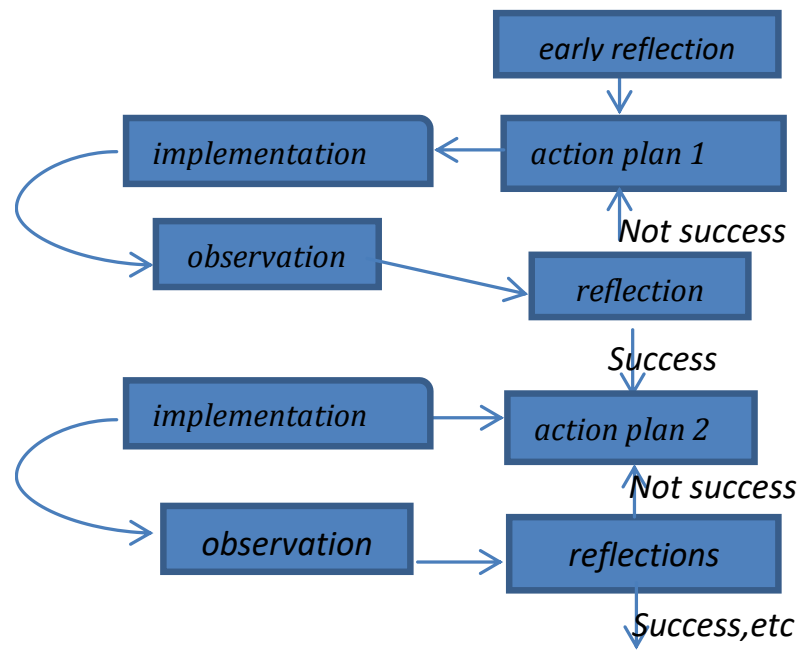

Fig. 1. Spiral Model of Kemmis and Taggar

In practice it is likely investigators already have a set plan of action (based on experience) so that it can directly start the stage action. There are also researchers who already have a set of data, so that they start the first activity with the activities of reflection. But in general, the researchers started from the initial phase of reflection to conduct a preliminary study as a 
basis for formulating research problems. Furthermore, the necessary planning, action, observation, and reflection can be described as follows.

\section{1) Early Reflection}

Early reflection assessments were intended to collect information on relevant situations to the research theme. The researcher and his team did a preliminary observation to recognize and know the true situation. The early reflection focused on problem and then was formulated into a research problem. Therefore, after the formulation of the problem is completed, further research is necessary to formulate a conceptual framework and can set research purposes. In the early reflection, the most prospective researchers examined the theories that are relevant to the issues to be studied.

\section{2) Preparation of planning}

All planning is based on the results of assessments of the early reflections. The detailed plan includes actions to be carried out to improve, enhance or change the behavior and attitudes of learners to be desired as the solution of problems. Be aware that this plan is flexible in the sense that can change according to the real conditions that exist. Early preparation is done in connection with a class action research including:

- determining the researcher/lecturer team to dig preliminary data on students characteristics formulates indicators for measuring the success of learning in accordance with the basic competencies that have been set.

- making learning quality assessment instruments faculty, student activities, student motivation, and skills of the students.

- preparing the teaching media materials in the form of handouts, video, active speakers, practical props (components engineering), handouts, and books diktat.

- validating and revising the instrument. Validation was done by the learning experts competent. Based on the expert input, then a team of researchers revise the instrument.

\section{3) Job action}

Implementation of stating what actions conducted by researchers in an attempt repair, improvement or change was implemented based on the action plan. The type of action that was taken in the practice class act should always be based on theoretical and empirical consideration for the results obtained in the form of improved performance and results of the program are optimal. In this study, the actions to be carried out are the use of multimedia and practical subjects props Hydrology. At the time of this action research, the team acted as lecturers and the other one acted as the observer.

\section{4) Observation}

In this activity, the researchers examined the results or the impact of actions taken or imposed on students. The observation was done by measuring the level of students learning motivation with the observation sheet filled out by the observer.

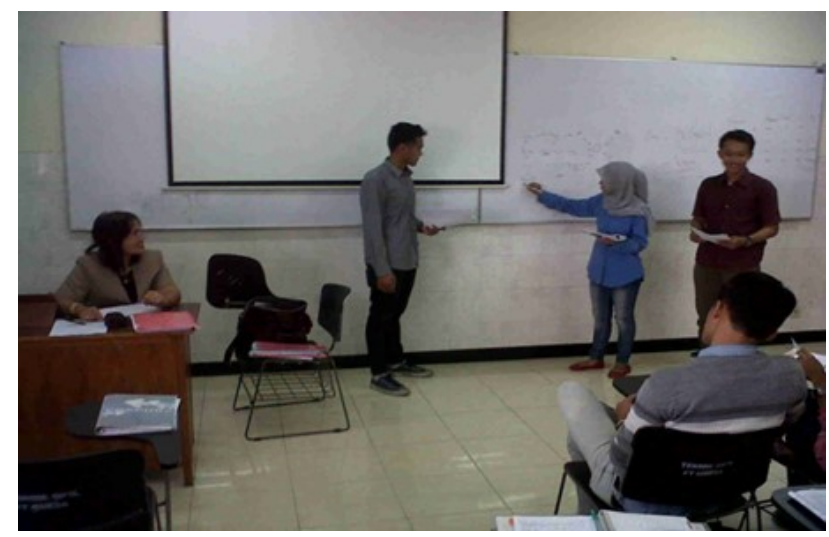

Fig. 2. Event examined the results of the action against learners

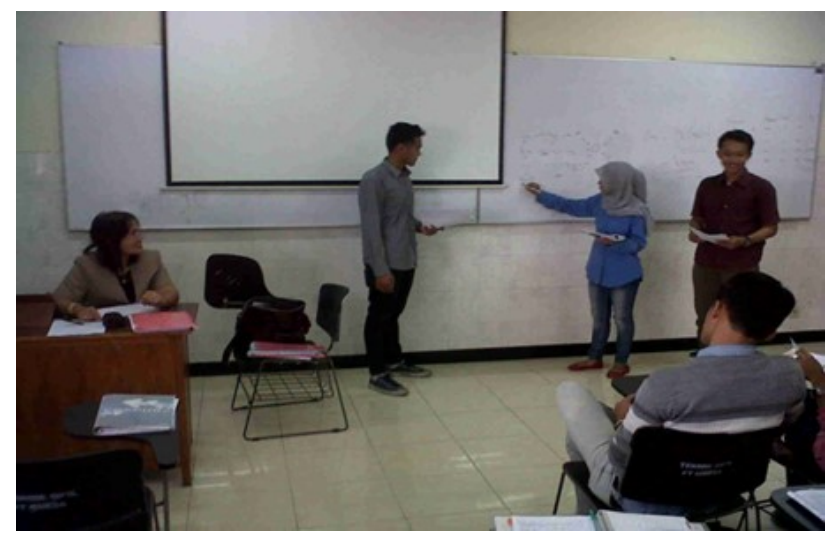

Fig. 3. Observation to measure students learning motivation level with the observation sheet filled out by the observer

\section{5) Reflection}

Reflection activity is an activity analysis, synthesis, interpretation of the information obtained during the action activities. In this activity, researchers examined, viewed, and considered the results or impact of the action. Any information collected needed to be studied linked with one another and their relation to the theory or research results that already exist and are relevant. Through a deep reflection, it can be concluded that it was steady and sharp. Reflection is a very important part of observation to understand the processes and outcomes that occur, namely in the form of change as a result of the action taken.

In essence of the Kemmis and Taggart model in the form of devices or strands with each device consists of four components, namely planning, action, observation, and reflection is seen as a cycle. The number of cycles depends on the problems that need to be solved, which is generally more than one cycle. Each cycle is expected to achieve the success at a certain level to really achieve the expected goals.

\section{B. Research Subjects}

The subjects of this study were the students of Civil Engineering Education class PTB-B as many as 36 students on the odd semester of 2015/2016 at the Department of Civil Engineering, FT UNESA on Hydrology subject. 


\section{Location of the Research and Study Time}

This study was conducted in Civil engineering classroom of UNESA in A1O3O8 building.

\section{Data Collection Techniques and Research Instruments}

Data collection techniques in this study were interviews, observation, and questionnaires. The research instruments were in the form of guidelines for observation, questionnaire, student worksheets and texts/the test.

\section{E. Data Analysis Techniques}

To get the application of PBL model, there was a need to analyze the data. Data analysis is the process of simplification of data into a form that is more easily understood and interpreted. Data analysis in this research is the Qualitative Data Analysis Techniques which can be described as follows:

1) Each item is scored according to the answers grading scale that is in the observation sheets and students motivation questionnaires.

2) The total score then presented descriptively using a predetermined formula.

a) Analysis of Teaching and Learning Activities: Observation/observations were made every meeting by two (2) observers to fill in the observation sheet that is in accordance with procedures. Observations were made during the preparation, introduction, core activities, closing, time management and control of the classroom atmosphere. Grading in the observation sheet has a score that was converted in the form of a rubric (Table II). Then the average score of observation of each stage were already observed is described by a category which has also been determined (Table III).

\begin{tabular}{|c|l|c|}
\multicolumn{2}{c}{ TABLE II. $\quad$ VALUE SCORE CONVERSION } \\
\hline Score & \multicolumn{1}{|c|}{ Description } & Criteria \\
\hline 1 & Done, but not finished & not good \\
\hline 2 & Do, is less appropriate, unsystematic & not good \\
\hline 3 & Done, appropriate and less systematic & pretty good \\
\hline 4 & Done, appropriate and systematic & Good \\
\hline
\end{tabular}

TABLE III. THE AVERAGE VALUE OF OBSERVATION

\begin{tabular}{|c|c|}
\hline Average & Description \\
\hline $1,00-1,99$ & not good \\
\hline $2,00-2,99$ & not good \\
\hline $3,00-3,49$ & pretty good \\
\hline $3,50-4,00$ & good \\
\hline
\end{tabular}

While data on the learning activities continued with a simple statistical analysis descriptive in terms of percentage $(\%)$. The number of values taken from each activity was divided by the number of observer and multiplied by $100 \%$ while using the same instrument. Observations were made every 10 minutes once for each SAP/cycle.

b) Analysis of Student Learning Motivation: To find out the result of increased students motivation to learn, use calculation of the percentage of questionnaires. Each item response corresponding statement lattice questionnaire described quantitatively into scoring. The results of the questionnaire are summed stuffing, starting the cycle all cycles 1 to $i$, then in percentage to obtain a picture of students learning motivation with Problem Based Learning (PBL) model and the prescribed method using the integrated multimedia as one of the supporting infrastructures.

TABLE IV. SCORING ITEM QUESTIONNAIRE STATEMENT

\begin{tabular}{|c|c|}
\hline Scoring point statement & Description \\
\hline 1 & strongly disagree \\
\hline 2 & disagree \\
\hline 3 & doubtful \\
\hline 4 & agree \\
\hline 5 & strongly agree \\
\hline
\end{tabular}

The data obtained from each cycle were percentage and analyzed using the following formula:

$P A=\frac{\text { Total Score Item of Questionnaire }}{\text { Number of Students }} \times 100 \%$

Information:

$\mathrm{PA}=$ Percentage Questionnaire

\section{CONCLUSIONS}

Observations were made during the preparation, introduction, core activities, closing, time management and control of the classroom atmosphere. Then, the average score of observation of each stage that was already observed is described by a category which has also been determined. The number of values taken from each activity was divided by the number of observer and multiplied by $100 \%$ while using the same instrument. Observations were made every 10 minutes once for each SAP/cycle. To find out the result of increased student motivation to learn, use calculation of the percentage of questionnaires. Each item response corresponding statement lattice questionnaire was described quantitatively into scoring.

\section{REFERENCES}

[1] S. Arikunto, "Prosedur Penelitian Suatu Pendekatan Praktik," Jakarta: PT. Rineka Cipta, 2009.

[2] S. Arikunto, "Dasar-dasar Evaluasi Pendidikan," Jakarta: Bumi Aksara, 2001.

[3] O. Hamalik, "Proses Belajar Mengajar," Jakarta: PT. Bumi Aksara, 2001.

[4] S. Herminarto, "Implementasi pembelajaran berbasis proyek pada bidang kejuruan," Cakrawala Pendidikan. Yogyakarta: LPM UNY, 2006.

[5] S.F. Krar, J.W. Amand, J.E.St. Oswald, "Machine Tool Operation's," McGraw Hill, USA, 1996.

[6] M. Nur, "Model Pembelajaran Berdasarkan Masalah," Surabaya: Pusat Sains danMatematika Sekolah UNESA, 2011. 